\title{
LIFE-HISTORY TRAITS OF CHLOROSCOMBRUS CHRYSURUS (ACTINOPTERYGII: PERCIFORMES: CARANGIDAE) IN TROPICAL WATERS OF THE ATLANTIC OCEAN
}

\author{
Joyce D.G.R. DE QUEIROZ ${ }^{1}$, Nathallia L.A. SALVADOR ${ }^{1}$, Marcia F. SOUSA ${ }^{2}$, \\ Victor E.L. DA SILVA ${ }^{2 *}$, Nidia N. FABRÉ ${ }^{2}$, and Vandick S. BATISTA ${ }^{1}$ \\ ${ }^{1}$ Laboratory of Conservation and Management of Fishery Resources, Federal University of Alagoas, Maceió, Brazil \\ ${ }^{2}$ Laboratory of Ecology, Fish and Fisheries, Federal University of Alagoas, Maceió, Brazil
}

\begin{abstract}
De Queiroz J.D.G.R., Salvador N.L.A., Sousa M.F., Da Silva V.E.L., Fabré N.N., Batista V.S. 2018. Lifehistory traits of Chloroscombrus chrysurus (Actinopterygii: Perciformes: Carangidae) in tropical waters of the Atlantic Ocean. Acta Ichthyol. Piscat. 48 (1): 1-8.
\end{abstract}

Background. In fishery biology, information on life-history traits is extremely useful for species conservation and the monitoring, management and sustaining of fish stocks. Nevertheless, detailed biological information is very limited for tropical fishes, especially for those with low economic value, such as the Atlantic bumper, Chloroscombrus chrysurus (Linnaeus, 1766). This species is commonly captured by artisanal fisheries in tropical waters and the lack of information makes difficult the development of strategies for the proper management of the species. Therefore, the presently reported study intended to provide new data on the biological parameters of $C$. chrysurus to fill the gap in the existing knowledge.

Materials and methods. Life-history traits of the Atlantic bumper, C. chrysurus, were estimated from 335 fish collected in a western Atlantic region during fishery surveys carried out between 2010 and 2012. Age and growth were determined by annuli counts of sagittal otoliths. Growth parameters were calculated by adjusting the backcalculated length-per-age to the von Bertalanffy growth model. Empirical equations and data on maturity were used to estimate the size and age at first maturity, as well as the optimum size and age. Theoretical longevity and natural mortality were also estimated for the species.

Results. Six age classes were identified and asymptotic length $\left(L_{\infty}\right)$, growth rate $(k)$, and the theoretical age when the specimen was at zero length $\left(t_{0}\right)$ for the whole population assumed the following values: $L_{\infty}=25.49 \mathrm{~cm}$, $k=0.32$ year $^{-1}$, and $t_{0}=0.058$ years. No evidence of sexual size dimorphism was found, with no significant differences in growth characteristics and in the length frequency distribution between sexes. The principal vital parameters were as follows: size $\left(L_{50}=15.5 \mathrm{~cm}\right)$ and age $\left(T_{50}=2.9+\right)$ at sexual maturity, optimum length $\left(L_{\text {opt }}=13.08 \mathrm{~cm}\right)$, and optimum age $\left(T_{\text {opt }}=2.1+\right)$, as well as its theoretical longevity $\left(A_{0.95}=9.17\right)$ and natural mortality $(M=0.92)$.

Conclusion. The determined size and age at sexual maturity, optimum length and age, theoretical longevity, and natural mortality indicate that the studied population of $C$. chrysurus is overexploited. The Atlantic bumper is vulnerable to fishing pressure and should be managed with caution.

Keywords: age determination, fish growth, longevity, natural mortality, otolith

\section{INTRODUCTION}

Global changes have impacted ecosystems in many different ways by changing food web structures (Kolar and Lodge 2000), affecting productivity levels (Loustau et al. 2005), and even allowing species to extend their distribution range throughout the globe (Juárez et al. 2008, Tavera et al. 2008). A good example, though not the only one, is the occurrence of the Atlantic bumper, Chloroscombrus chrysurus (Linnaeus, 1766), in Spanish waters, Gulf of Cádiz (Acosta et al. 2009), and in the
Mediterranean Sea (Peña Rivas et al. 2013). The extension of the distribution range of this species may be linked to many factors, but especially to the current warming of the North Atlantic (Stebbing et al. 2002). In fact, some authors have predicted that warming conditions are likely to increase chances of survival and future naturalization of C. chrysurus in these regions (Acosta et al. 2009, Peña Rivas et al. 2013), which may result in several ecological and economic impacts (e.g., reducing and impacting native wildlife populations).

\footnotetext{
" Correspondence: Victor Emmanuel Lopes da Silva, Universidade Federal de Alagoas, Instituto de Ciências Biológicas e da Saúde, Laboratório de Ecologia, Peixes e Pesca, Av. Lourival Melo Mota - Tabuleiro do Martins, 57072-900, Alagoas, Brazil, phone: +55 82 9-9843-9768, e-mail: (VELS) lopesdasilvavictor@gmail.com, (JDGRQ) joyce-queiroz@hotmail.com, (NLAS) nathalliasalvador@gmail.com, (MFS) marcia_ufal@hotmail.com, (NNF) nidia.fabre@pq.cnpq.br, (VSB)vandickbatista@gmail.com.
} 
Faced with this prediction, it is extremely concerning that available information on biological parameters of Chloroscombrus chrysurus is still very scarce, especially for tropical regions where the species is widely distributed (Cunha et al. 2000, Campos et al. 2010). For instance, studies on growth parameters of $C$. chrysurus, up to now, have only been carried out with larvae in subtropical regions (Leffler and Shaw 1992, Sánchez-Ramárez and Flores-Coto 1998), and with data based on length frequency (García and Duarte 2006, Sossoukpe et al. 2017). Analyses of structures that can provide more consistent results, such as otoliths, have not been incorporated into these studies so far.

The correct estimation of life-history traits of this species is not only important for its conservation, but also for the development of management strategies, especially with the current extension of its distribution range (Peña Rivas et al. 2013). Therefore, the presently reported study aims to contribute with current knowledge on the biology of $C$. chrysurus by estimating its life-history traits in tropical waters using a combination of otolith analysis and empirical equations to provide enough information on this species' age, growth, population structure, maturity, longevity, and natural mortality.

\section{MATERIAL AND METHODS}

Fish were sampled in a western Atlantic region at the central coast of Alagoas, Brazil (centroid at $9^{\circ} 67^{\prime} 40^{\prime \prime} \mathrm{S}$ and $35^{\circ} 72^{\prime} 31^{\prime \prime} \mathrm{W}$, Fig. 1), during fishery surveys carried out between May 2010 and April 2012. Samples were collected monthly using two different fishing gears: a beach seine net (mesh size: 140 to $254 \mathrm{~mm}$ ) used to catch

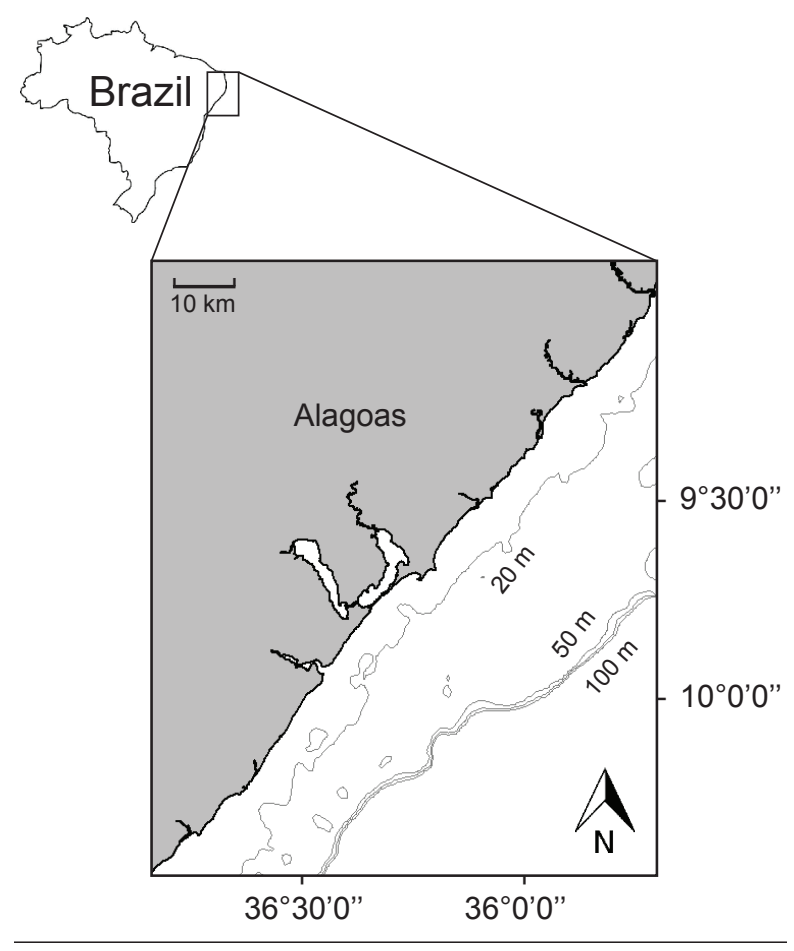

Fig. 1. Map of the study area, located in the coast of Alagoas, Brazil juveniles (total length: $2-14 \mathrm{~cm}$ ) and a gillnet (25 to 170 $\mathrm{mm})$ to collect adults $(15-25 \mathrm{~cm})$. In the laboratory, fish individuals were identified to species level following Menezes and Figueiredo (1980), measured to the nearest $1 \mathrm{~cm}$ (total length), weighted (in grams), sexed, and assigned to a maturity stage using macroscopic gonadal examination following Vazzoler (1996).

The sagittae otoliths of each individual were removed, cleaned, dried, and stored in labelled vials for subsequent examination. Prior to analysis, to accomplish a better visualization of growth rings, otoliths were immersed in pure alcohol for $24 \mathrm{~h}$ until decalcification. Subsequently, a picture of otoliths submerged in pure alcohol and sulcus placed downwards was taken using a binocular stereoscope microscope Leica S8-APO (25-40 times magnification) with reflected light against a dark background. Age determination was achieved by counting growth rings, which were considered to be formed by one opaque band and one translucent band together (Fig. 2). Each otolith was read independently at least twice for two different readers with no prior information regarding length or sex. Later, differences in age estimation between readers were tested by a Student's $t$-test.

The periodicity of annulus formation was verified by the relative marginal increment analysis (MIA)

$$
\mathrm{MIA}=\frac{R_{\mathrm{t}}-R_{\mathrm{nc}}}{R_{\mathrm{nc}}-R_{\mathrm{nc}-1}}
$$

where $R_{\mathrm{t}}$ is the total radius of the otolith; $R_{\mathrm{nc}}$, the distance between the nucleus and last ring; and $R_{\mathrm{nc}-1}$, the distance between the nucleus and next-to-last ring formed (Branstetter and Musick 1994). Analysis of variance (ANOVA) was carried out to test significant differences in the MIA throughout the year, and monthly MIA values were compared to rainfall data $[\mathrm{mm}]$ by a linear regression to determine trends in bands formation.

To estimate the growth parameters of Chloroscombrus chrysurus, we first used the back-calculation model of Morita and Matsuishi (2001) to remove bias due to age effects (Wilson et al. 2009). This model assumes that otolith radius results from a linear combination of both fish length and age (Wilson et al. 2009) and it is calculated as follows

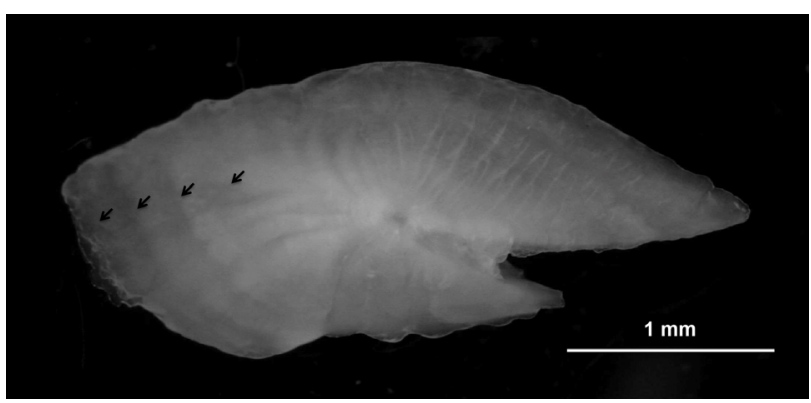

Fig. 2. Otolith of Chloroscombrus chrysurus caught in the tropical Atlantic Ocean; arrows indicate growth rings 


$$
L_{t}=-\frac{\alpha}{\beta}+\left(L_{T}+\frac{\alpha}{\beta}+\frac{\gamma}{\beta} T\right) \frac{O_{t}}{O_{T}}-\frac{\gamma}{\beta} t
$$

where $L_{t}$ is the back-calculated fish body length at age $t$; $L_{T}$ is the fish body length at time of capture $T ; O_{t}$ is the otolith length at annulus (age) $t$; $O_{T}$ is the otolith length at the time of capture $T$; and $\alpha, \beta$, and $\gamma$ are the constants obtained from the multiple linear regression analysis. Growth in length was then modelled by the von Bertalanffy growth model (VBGM) using a nonlinear regression

$$
L_{t}=L_{\infty}\left(1-e^{-k\left(t-t_{0}\right)}\right)
$$

where $L_{t}$ is the length at age $t ; L_{\infty}$ is the theoretical asymptotic total length; $k$ is the growth coefficient describing the rate of growth [year ${ }^{-1}$ ] towards $L_{\infty}$, and $t_{0}$ is the hypothetical age (in years) at a total length of zero. The VBGM was estimated for males, females and the whole population (both sexes combined and specimens with indeterminate sex).

Length at first maturity $\left(L_{50}\right)$ for the whole population was estimated by fitting a logistic model using the percentage of mature individuals per $1 \mathrm{~cm}$ size class (King 2007)

$$
Y=\frac{1}{1+e^{-(a+b X)}}
$$

where, $Y$ is the percentage of mature individuals at a length $X$, and $a$ and $b$ are the resulted constants. The model was fitted using a log-transformed abundance of individuals per size class and the size where $50 \%$ of individuals were mature was assessed by $-a \cdot b^{-1}$. Age at sexual maturity $\left(t_{50}\right)$ was known by using the inverse version of the growth equation as suggested by King (2007)

$$
t_{50}=t_{0}-\left(\frac{1}{k}\right) \cdot \ln \left(\frac{1-L_{50}}{L_{\infty}}\right)
$$

Estimated growth parameters were also used to calculate natural mortality $(M)$, length at maximum yield per recruit $\left(L_{\mathrm{opt}}\right)$, optimum age $\left(T_{\mathrm{opt}}\right)$, and longevity, defined as the time that individuals take to achieve $95 \%$ of the asymptotic length $\left(A_{0.95}\right)$. Natural mortality $(M)$ was calculated by Pauly's empirical equation

$$
\begin{gathered}
\log M=-0.0066- \\
-0.279 \cdot \log L_{\infty}+0.6543 \cdot \log k+ \\
+0.4634 \cdot \log \text { Temp }
\end{gathered}
$$

where $L_{\infty}$ and $k$ are the von Bertalanffy growth parameters, and Temp is the mean water temperature $\left({ }^{\circ} \mathrm{C}\right.$ ) (Pauly 1980). Data on annual sea surface temperature was retrieved from the Brazilian National Institute of Meteorology
(INMET) and the mean value of $29.87^{\circ} \mathrm{C}$ was incorporated into the equation.

The length at maximum yield per recruit $\left(L_{\mathrm{opt}}\right)$, which expresses the length at which natural mortality equals to growth rate was calculated following Beverton (1992)

$$
L_{\mathrm{opt}}=3 L_{\infty}\left(3+M k^{-1}\right)^{-1}
$$

where $M$ is the natural mortality and $L_{\infty}$ and $k$ are the estimated growth parameters from the VBGM. Optimum age $\left(T_{\text {opt }}\right)$, the age where fish reaches its highest biomass, was estimated by the equation of Krishnan Kutty and Qasim (1968)

$$
T_{\text {opt }}=t_{0}+\frac{\ln (3 k+M)-\ln M}{k}
$$

Theoretical longevity, here defined as the time that individuals take to achieve $95 \%$ of the asymptotic length, was calculated using the equation described by Taylor (1958)

$$
A_{0.95}=t_{0}-\frac{\ln \left(1-L_{\infty}\right)}{k}
$$

where, $L_{\infty}, k$, and $t_{0}$ are the estimated growth parameters. Maximum and minimum values (standard errors) of $t_{0}$ and $k$ (growth parameters) were used to estimate longevity confidence intervals.

We also examined sexual size dimorphism in species total length by analysis of variance (ANOVA). Data was previously tested for normality and homoscedasticity using Shapiro-Wilk and Levene's tests, respectively. Additionally, length-weight relations (LWR) for females, males, and the whole population were estimated by linear regressions using the equation

$$
\log W=\log a+b \cdot \log T L
$$

where $W$ is the body weight, TL is the total length, $a$ is the intercept, and $b$ is the slope (Le Cren 1951, Froese 2006).

Statistical analyses were all carried out with the software R statistics (version 3.1.3) at a significance level of $P<0.05$.

\section{RESULTS}

In this study, a total of 335 fish were included in the estimation of population parameters of Chloroscombrus chrysurus. Out of all individuals, 133 were females, 100 were males, and in 102 sex could not be determined. Total length ranged from 2.5 to $26.4 \mathrm{~cm}$ (considering all specimens, including the individuals of undetermined sex), and no evidence of sexual size dimorphism was found (ANOVA, $P>0.05$, Fig. 3). LWR parameters and related statistics are given in Table 1. All regressions were highly significant $(P<0.01)$ with correlation coefficients $\left(r^{2}\right)$ of $0.76,0.80$, and 0.98 to males, females, and the whole population, respectively. 
No suitable samples were collected in June for calculating the MIA. Yet, marginal increments were significantly different among months (ANOVA, $P<0.01$ ), with increments presenting a trend of increasing monthly until reaching its peak in May, followed by a decrease in their value starting in July (Fig. 4). Furthermore, changes in marginal increment were significantly correlated to seasonal fluctuations in rainfall rates $\left(P<0.01, r^{2}=0.44\right)$.
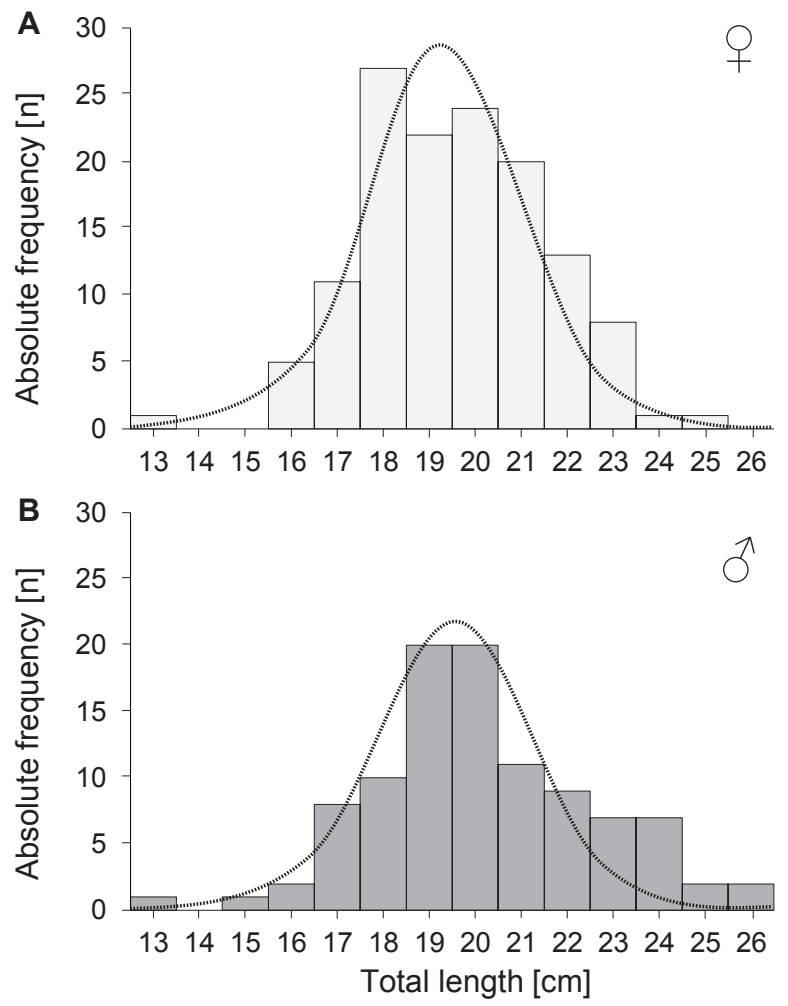

Fig. 3. Length frequency distribution of females (A) and males (B) of Chloroscombrus chrysurus in the tropical Atlantic Ocean

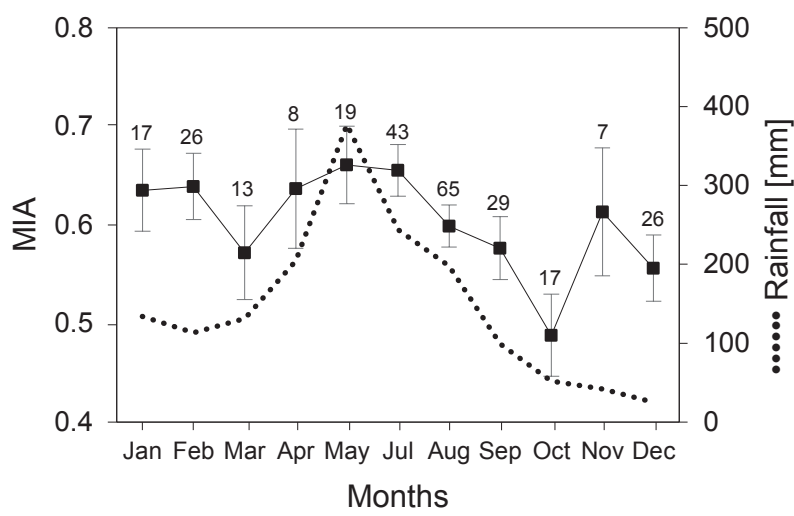

Fig. 4. Annual variation in the marginal increment analysis (MIA) of Chloroscombrus chrysurus and the relation between monthly values and rainfall levels; number of otoliths used to get mean values are presented above error bars
Both readers' age estimates were symmetrical $(P<$ $0.05)$. Estimated ages for Atlantic bumper ranged from $0^{+}$to $6^{+}$, though the majority of fish sampled belonged to $3^{+}$and $4^{+}$ age classes $(60.89 \%)$. Observed growth parameters did not differ between sexes (Table 2), hence the von Bertalanffy growth curve was recalculated using all specimens, including the individuals with indeterminate sex (Fig. 5, $\left.r^{2}=0.88, n=335\right)$. Information on growth parameters, theoretical longevity $\left(A_{0.95}\right)$ and natural mortality $(M)$ for C. chrysurus are summarized in Tables 2 and 3.

The size at first maturity $\left(L_{50}\right)$ for $C$. chrysurus was $15.5 \pm 2.8 \mathrm{~cm}$ (Fig. 6), and the age at sexual maturity $\left(T_{50}\right)$ was $2.9^{+}$years $^{-1}$. Optimum length and age were smaller than the $L_{50}$ and $T_{50}$, being $13.08 \mathrm{~cm}$ and $2.1^{+}$years $^{-1}$, respectively.

\section{DISCUSSION}

This study represents the first comprehensive reference on age and growth estimation for Chloroscombrus chrysurus based on otolith analyses. The use of otoliths in age estimation for tropical fish was previously considered infeasible due to complex interactions between physiological and environmental factors (Blaber 2002), as well as miscounts of growth rings (Brothers et al. 1976).

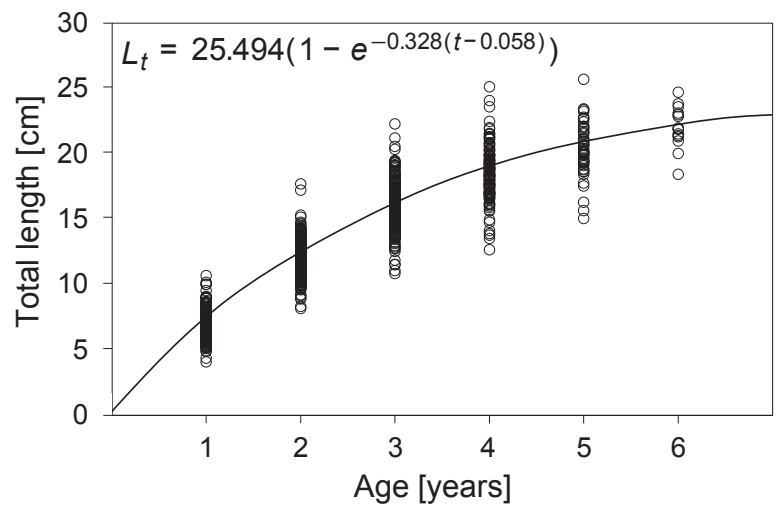

Fig. 5. Relation between observed total length and age for Chloroscombrus chrysurus in the tropical Atlantic Ocean $(n=335)$, showing von Bertalanffy growth function

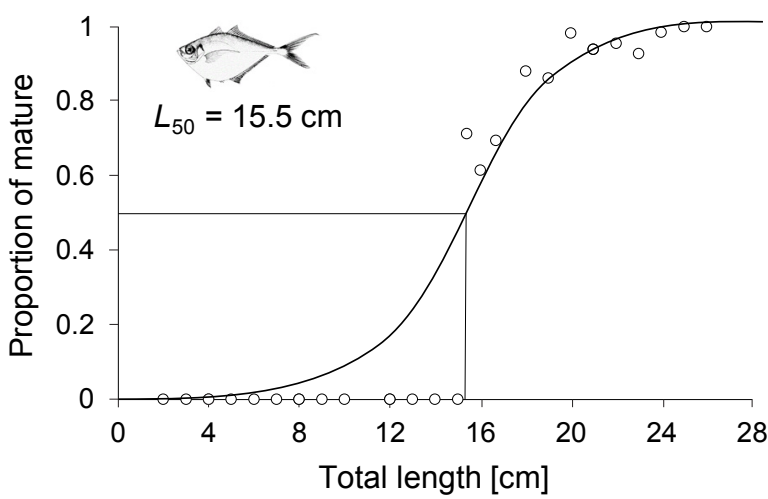

Fig. 6. Size at first maturity for Chloroscombrus chrysurus in the tropical Atlantic Ocean 
Table 1

Descriptive statistics and estimated parameters

of length-weight relations for Chloroscombrus chrysurus caught in tropical waters of the Atlantic Ocean between May 2010 and March 2011, and from August 2011 through April 2012

\begin{tabular}{|c|c|c|c|c|c|c|c|c|}
\hline \multirow{2}{*}{ Sex } & \multirow{2}{*}{$n$} & \multirow{2}{*}{ Length $[\mathrm{cm}]$} & \multirow{2}{*}{ Weight $[\mathrm{g}]$} & \multicolumn{5}{|c|}{ LWR parameters } \\
\hline & & & & $a$ & $95 \%$ CI of $a$ & $b$ & $95 \%$ CI of $b$ & $r^{2}$ \\
\hline Female & 133 & $13.9-25.3$ & $24.2-131.6$ & 0.004 & $0.002-0.011$ & 3.19 & $2.92-3.46$ & 0.80 \\
\hline Male & 100 & $13.7-26.4$ & $24.4-138.5$ & 0.014 & $0.005-0.037$ & 2.81 & $2.50-3.12$ & 0.76 \\
\hline Population & 355 & $2.5-26.4$ & $0.1-138.5$ & 0.013 & $0.012-0.015$ & 2.84 & $2.80-2.88$ & 0.98 \\
\hline
\end{tabular}

$n=$ number of individuals, $a=$ intercept, $b=$ slope (of LWR), 95\% CI $=95 \%$ confidence intervals range (of $a$ and $b$ ), $r^{2}$, correlation coefficient.

Table 2

The von Bertalanffy growth parameters estimated for Chloroscombrus chrysurus caught in tropical waters of the Atlantic Ocean between May 2010 and March 2011, and from August 2011 through April 2012

\begin{tabular}{lcccc}
\hline \multirow{2}{*}{ Sex } & \multirow{4}{c}{$n$} & \multicolumn{3}{c}{ Growth parameter } \\
\cline { 3 - 5 } & & $L_{\infty}[\mathrm{cm}]$ & $k\left[\right.$ year $\left.^{-1}\right]$ & $t_{0}$ \\
\hline Female & 133 & $25.619 \pm 0.805$ & 0.323 & $0.032 \pm 0.045$ \\
Male & 100 & $26.438 \pm 1.218$ & 0.316 & $0.057 \pm 0.064$ \\
$\begin{array}{l}\text { Whole } \\
\text { population }\end{array}$ & 355 & $25.494 \pm 0.640$ & 0.328 & $0.058 \pm 0.035$ \\
\hline
\end{tabular}

$n=$ number of individuals, $L_{\infty}=$ theoretical asymptotic total length, $k=$ growth rate, $t_{0}=$ hypothetical age at a total length of zero.

Nevertheless, the results presented herein, such as the symmetrical counting of growth rings between different readers and the marginal increment analysis, show that these structures can provide consistent information on growth characteristics for $C$. chrysurus.

Marginal increment analysis (MIA) indicated a clear trend in bands formation (see Fig. 4), demonstrating that growth rings of Chloroscombrus chrysurus are formed once a year and are strongly correlated to seasonal changes in rainfall rates. Increment bands may be associated with both environmental conditions and cyclical biological process (Morales-Nin and Panfili 2005), depending on life-history requirements of species (Sousa et al. 2015). For many tropical species, a strong relation between rainfall and growth has been previously reported (Bwanika et al. 2007, Ong et al. 2015, Sousa et al. 2015, Efitre et al. 2016). This relation results, mainly, from changes caused by rainfall in water physicochemical parameters (i.e., turbidity, salinity, and light penetration) and productivity levels (Barletta et al. 2005, Pereira et al. 2015), as these changes may provide better feeding condition for fish (Bergenius et al. 2005).

The von Bertalanffy growth curve fitted to our observed data adequately. Growth parameters estimated herein $\left(L_{\infty}=25.4 \mathrm{~cm}, k=0.32\right.$ year $\left.^{-1}, t_{0}=0.05\right)$ differed from those calculated for species using length-frequency data in south-eastern and southern Brazil $\left(L_{\infty}=45.1\right.$ $\mathrm{cm}, k=0.22$ year $\left.^{-1}, t_{0}=-0.65\right)$ by Cergole et al. (2006), and in Caribbean Sea $\left(L_{\infty}=30.5 \mathrm{~cm}, k=0.63\right.$ year $\left.^{-1}\right)$ by García and Duarte (2006). These differences may be
Table 3

Estimated theoretical longevity $\left(A_{095}\right)$ and natural mortality $(M)$ for Chloroscombrus chrysurus caught in tropical waters of the Atlantic Ocean between May 2010 and March 2011, and from August 2011 through April 2012

\begin{tabular}{lccccc}
\hline \multirow{2}{*}{ Sex } & \multicolumn{2}{c}{ Longevity [years] } & & \multicolumn{2}{c}{ Natural mortality [year ${ }^{-1}$ ] } \\
\cline { 2 - 3 } \cline { 5 - 6 } & $A_{0.95}$ & $95 \% \mathrm{CI}$ & & $M$ & $95 \% \mathrm{CI}$ \\
\hline Females & 9.30 & \pm 0.50 & & 0.926 & \pm 0.030 \\
Males & 9.53 & \pm 0.76 & & 0.905 & \pm 0.046 \\
Whole & 9.17 & \pm 0.44 & & 0.938 & \pm 0.027 \\
population & 9.17 & &
\end{tabular}

$A_{0.95}=$ the time that individuals take to achieve $95 \%$ of the asymptotic length.

associated with many factors (i.e., climate type, latitudinal differences) (Tarkan and Vilizzi 2015), but especially to the size range of individuals once growth parameters are very sensitive to samples-larger individuals tend to increase asymptotic length as growth rate decreases (Espino Barr et al. 2008). For example, in south-eastern/ southern Brazil, larger individuals of $C$. chrysurus have been reported, with species growing up to $42 \mathrm{~cm}$ (Cergole et al. 2006), while in the studied region the maximum length registered for the species was $30 \mathrm{~cm}$ (Lessa and de Nóbrega 2000). Furthermore, it is important to be noticed that methodological differences in age determination may unduly influence parameters estimation and, consequently, provide false impressions of the growth potential of fish species.

The lack of significant differences in growth characteristics between sexes found for Atlantic bumper appears to be very common among Carangidae species in tropical regions, such as Trachinotus botla (Shaw, 1803) (see Parker and Booth 2015) and Trachurus picturatus (Bowdich, 1825) (see Garcia et al. 2015). Although many factors may regulate sexual size dimorphism in species, mechanisms underlying these differences between sexes remain poorly understood (Fairbairn 2005, Young 2005). For example, even though studies have shown that environmental conditions may affect sexes differently, it appears that these changes are more consistent among larger taxa (Estlander et al. 2017). For smaller species, such as $C$. chrysurus, sexual size dimorphism is more understated and studies in larger scales (encompassing 
different latitudes) are necessary to a better understanding on patterns of body growth and size variation.

Both, length $\left(L_{\text {opt }}\right)$ and age $\left(T_{\text {opt }}\right)$ at maximum yield per recruit for Chloroscombrus chrysurus were smaller than the length $\left(L_{50}\right)$ and age $\left(T_{50}\right)$ at first maturity, which is a typical reproductive strategy of small fishes (Beverton 1992). As small fishes have high predation risk, and once maximum possible yield is determined by the ratio between growth and mortality, smaller species tend to reach maximum yield during younger ages and smaller sizes in a trade-off of reproduction and survival (Jensen 1996, Froese and Binohlan 2000).

Estimated natural mortality $\left(M=0.938\right.$ year $\left.^{-1}\right)$ was slightly smaller than the one reported for the species in the Caribbean Sea $\left(M=1.29\right.$ year $\left.^{-1}\right)$ (García and Duarte 2006). Yet, this value was expressively high when compared to other tropical carangid species, such as Trachurus declivis (Jenyns, 1841) $\left(M=0.63\right.$ year $\left.^{-1}\right)$ (Stevens and Hausfeld 1982). While similarities in mortality rates are expected among species in the same family (Pascual and Iribarne 1993), adaptations to local conditions and exploitation levels may cause these rates to vary. In the particular case of C. chrysurus, though not being considered a commercial target species, this species is frequently caught by artisanal fisheries in tropical regions, especially as by-catch (Ambrose et al. 2005, Alves et al. 2012, Cunha 2015). Indeed, our estimated theoretical longevity suggests that the Atlantic bumper may be vulnerable to fishing pressure, showing a high longevity $\left(A_{0.95}=9.17\right.$ years) despite its relatively small body size, which is a typical feature of overexploited species (Wiedmann et al. 2014).

In summary, Chloroscombrus chrysurus was found to be a small, fast growing, and long-lived fish. Such characteristics indicate that the species may be undergoing high levels of exploitation, and, therefore, should be managed with caution. We suggest that further studies of population structure of C. chrysurus incorporate geographic, climate, and fishery variables and hope that information provided herein may be used for developing management strategies for this species, as well as its conservation.

\section{ACKNOWLEDGMENTS}

We would like to thank colleague Dr Richard Ladle (Maceió/Brazil) for his assistance reviewing the English of the manuscript, as well as to all fishermen who kindly helped us during fish sampling. This work was partially supported by the Brazilian National Council for Scientific and Technological Development (CNPq) and the Funding Authority for Studies and Projects (FINEP).

\section{REFERENCES}

Acosta J.J., Muñoz I., Juárez A. 2009. First record of Chloroscombrus chrysurus (Osteichthyes, Carangidae) in the Spanish waters of the Gulf of Cadiz, (ICES Division IXa South). Marine Biodiversity Records 2: e41. DOI: 10.1017/S1755267208000250

Alves P.M.F., Arfelli C.A., Tomás A.R.G. 2012. Selectivity of bottom gillnet of southeastern Brazil. Boletim do Instituto de Pesca Pesca 38 (4): 275-284.
Ambrose E.E., Solarin B.B., Isebor C.E., Williams A.B. 2005. Assessment of fish by-catch species from coastal artisanal shrimp beam trawl fisheries in Nigeria. Fisheries Research 71 (1): 125-132. DOI: 10.1016/j. fishres.2004.07.005

Barletta M., Barletta-Bergan A., Saint-Paul U., Hubold G. 2005. The role of salinity in structuring the fish assemblages in a tropical estuary. Journal of Fish Biology 66 (1): 45-72. DOI: 10.1111/j.00221112.2005.00582.x

Bergenius M.A.J, McCormick M.I., Meekan M.G., Robertson D.R. 2005. Environmental influences on larval duration, growth and magnitude of settlement of a coral reef fish. Marine Biology 147 (2): 291-300. DOI: $10.1007 / \mathrm{s} 00227-005-1575-\mathrm{Z}$

Beverton R.J.H. 1992. Patterns of reproductive strategy parameters in some marine teleost fishes. Journal of Fish Biology 41 (Suppl. B): 137-160. DOI: 10.1111/ j.1095-8649.1992.tb03875.x

Blaber S.J.M. 2002. "Fish in hot water": The challenges facing fish and fisheries research in tropical estuaries. Journal of Fish Biology 61 (Suppl. A): 1-20. DOI: 10.1111/j.1095-8649.2002.tb01757.x

BranstetterS., MusickJ.A. 1994.Ageandgrowthestimates for the sand tiger in the northwestern Atlantic Ocean. Transactions of the American Fisheries Society 123 (2): 242-254. DOI: 10.1577/1548-8659(1994)123<0242: AAGEFT $>2.3 . \mathrm{CO} ; 2$

Brothers E.B., Mathews C.P., Lasker R. 1976. Daily growth increments in otoliths from larval and adult fishes. Fishery Bulletin 74 (1): 1-8.

Bwanika G.N., Murie D.J., Chapman L.J. 2007. Comparative age and growth of Nile tilapia (Oreochromis niloticus L.) in lakes Nabugabo and Wamala, Uganda. Hydrobiologia 589 (1): 287-301. DOI: $10.1007 / \mathrm{s} 10750-007-0746-y$

Campos P.N., de Castro M.S., Bonecker A.C.T. 2010. Occurrence and distribution of Carangidae larvae (Teleostei, Perciformes) from the southwest Atlantic Ocean, Brazil $\left(12-23^{\circ} \mathrm{S}\right)$. Journal of Applied Ichthyology 26 (6): 920-924. DOI: 10.1111/j.14390426.2010.01511.x

Cergole M.C., Ávila-da-Silva A.O., Rossi-Wongtschoski C.L.D.B. (eds.) 2006. Análise das principais pescarias comerciais da região sudeste-sul do Brasil: dinâmica populacional das espécies em explotação. [Analysis of the main commercial fisheries in the south-east region of Brazil: Population dynamics of the species under exploitation.] Série documentos REVIZEE - score sul. Instituto Oceanográfico - USP, São Paulo, Brazil. [In Portuguese.]

Cunha F.E.A. 2015. Caracterização da ictiofauna comercializada nos mercados públicos da cidade de Parnaíba, Piauí. [Characterization of the ichthyofauna sold in the public markets of the city of Parnaíba, Piauí.] Revista Brasileira de Engenharia de Pesca 8 (2): 13-25. [In Portuguese.]

Cunha F.E.A., Freitas J.E.P., Feitosa C.V., MonteiroNeto C. 2000. Biologia e biometria da palombeta, 
Chloroscombrus chrysurus (Linnaeus, 1766)(Teleostei: Carangidae), em Fortaleza, Ceará, Brasil. [Biology and biometry of the Atlantic bumper, Chloroscombrus chrysurus (Linnaeus, 1766) (Teleostei: Carangidae), in Fortaleza, Ceará, Brazil.] Arquivos de Ciência do Mar 33 (1-2): 143-148. [In Portuguese.]

Efitre J., Murie D.J., Chapman L.J.2016. Age validation, growth and mortality of introduced Tilapia zillii in Crater Lake Nkuruba, Uganda. Fisheries Management and Ecology 23 (1): 66-75. DOI: 10.1111/fme.12163

Espino Barr E., Gallardo Cabello M., Cabral Solís E.G., Garcia Boa A., Puente Gómez M. 2008. Growth of the Pacific jack Caranx caninus (Pisces: Carangidae) from the coast of Colima, México. Revista de Biologia Tropical 56 (1): 171-179.

Estlander S., Kahilainen K.K., Horppila J., Olin M., Rask M., Kubečka J., Peterka J., Říha M., Huuskonen H., Nurminen L. 2017. Latitudinal variation in sexual dimorphism in life-history traits of a freshwater fish. Ecology and Evolution 7 (2): 665673. DOI: $10.1002 /$ ece 3.2658

Fairbairn D.J. 2005. Allometry for sexual size dimorphism: Testing two hypotheses for Rensch's rule in the water strider Aquarius remigis. The American Naturalist 166 (Suppl. 4): S69-S84. DOI: $10.1086 / 444600$

Froese R. 2006. Cube law, condition factor and weightlength relationships: History, meta-analysis and recommendations. Journal of Applied Ichthyology 22 (4): 241-253. DOI: 10.1111/j.1439-0426.2006.00805.x

Froese R., Binohlan C. 2000. Empirical relationships to estimate asymptotic length, length at first maturity and length at maximum yield per recruit in fishes, with a simple method to evaluate length frequency data. Journal of Fish Biology 56 (4): 758-773. DOI: $10.1111 /$ j.1095-8649.2000.tb00870.x

Garcia A., Pereira J.G., Canha Â., Reis D., Diogo H. 2015. Life history parameters of blue jack mackerel Trachurus picturatus (Teleostei: Carangidae) from north-east Atlantic. Journal of the Marine Biological Association of the United Kingdom 95 (2): 401-410. DOI: $10.1017 / \mathrm{S} 0025315414001751$

García C.B., Duarte L.O. 2006. Length-based estimates of growth parameters and mortality rates of fish populations of the Caribbean Sea. Journal of Applied Ichthyology 22 (3): 193-200. DOI: 10.1111/j.14390426.2006.00720.x

Jensen A.L. 1996. Beverton and Holt life history invariants result from optimal trade-off of reproduction and survival. Canadian Journal of Fisheries and Aquatic Sciences 53 (4): 820-822. DOI: 10.1139/f95-233

Juárez A., Silva L., Gil J. 2008. First record of Selene dorsalis (Osteichthyes: Carangidae) in the Spanish waters of the Gulf of Cádiz (ICES Division IXa South). Marine Biodiversity Records 1: e28. DOI: 10.1017/ S1755267206002612

King M. 2007. Fisheries biology, assessment and management. Blackwell Publishing, Oxford, UK.
Kolar C.S., Lodge D.M. 2000. Freshwater nonindigenous species: interactions with other global changes. Pp. 3-30. In: Hobbs R.J. (eds.) Invasive species in a changing world. Island Press, Washington, DC, USA.

Krishnan Kutty M., Qasim S.Z. 1968. The estimation of optimum age of exploitation and potential yield in fish populations. Journal du Conseil international pour l'Exploration de la Mer 32 (2): 249-255. DOI: 10.1093/ icesjms/32.2.249

Le Cren E.D. 1951. The length-weight relationship and seasonal cycle in gonad weight and conditions in the perch (Perca fluviatilis). Journal of Animal Ecology 20 (2): 201-219. DOI: $10.2307 / 1540$

Leffler D.L., Shaw R.F. 1992. Age validation, growth, and mortality of larval Atlantic bumper (Carangidae: Chloroscombrus chrysurus) in the northern Gulf of Mexico. Fishery Bulletin 90 (4): 711-719.

Lessa R., Nóbrega M.D. (eds.) 2000. Guia de identificação de peixes marinhos da região nordeste. [Fish identification guide for marine fishes of the north-eastern region.] Programa REVIZEE, scoreNE. DIMAR, Recife, Brazil. [In Portuguese.]

Loustau D., Bosc A., Colin A., Ogée J., Davi H., François C., Dufrêne E., Déqué M., Cloppet E., Arrouays D., Le Bas C., Saby N., Pignard G., Hamza N., Granier A., Bréda N., Ciais P., Viovy N., Delage F., 2005. Modeling climate change effects on the potential production of French plains forests at the sub-regional level. Tree Physiology 25 (7): 813-23. DOI: $10.1093 /$ treephys/25.7.813

Menezes N., Figueiredo J.L. 1980. Manual de peixes marinhos do sudeste do Brasil. IV. Teleostei (3). [Manual of marine fishes from the southeast of Brazil. IV. Teleostei (3).] Museu de Zoologia, Universidade de São Paulo, São Paulo, Brazil. [In Portuguese.]

Morales-Nin B., Panfili J. 2005. Seasonality in the deep sea and tropics revisited: What can otoliths tell us? Marine and Freshwater Research 56 (5): 585-598. DOI: $10.1071 / \mathrm{MF} 04150$

Morita K., Matsuishi T. 2001. A new model of growth back-calculation incorporating age effect based on otoliths. Canadian Journal of Fisheries and Aquatic Sciences 58 (9): 1805-1811. DOI: 10.1139/f01-126

Ong J.J.L., Rountrey A.N., Meeuwig J.J., Newman S.J., Zinke J., Meekan M.G. 2015. Contrasting environmental drivers of adult and juvenile growth in a marine fish: Implications for the effects of climate change. Scientific Reports 5: art. 10859. DOI: 10.1038/ srep10859

Parker D., Booth A.J. 2015. Aspects of the biology and life history of largespot pompano, Trachinotus botla, in South Africa. Marine and Freshwater Research 66 (3): 247-255. DOI: 10.1071/MF14029

Pascual M.A., Iribarne O.O. 1993. How good are empirical predictions of natural mortality? Fisheries Research 16 (1): 17-24. DOI: 10.1016/01657836(93)90107-I

Pauly D. 1980. On the interrelationships between natural mortality, growth parameters, and mean environmental 
temperature in 175 fish stocks. Journal du Conseil international pour l'Exploration de la Mer 39 (2): 175-192. DOI: 10.1093/icesjms/39.2.175

Peña Rivas L., Azzurro E., Lloris D. 2013. First record of the Atlantic bumper Chloroscombrus chrysurus (Teleostei: Carangidae) in the Mediterranean Sea. Journal of Fish Biology 82 (3): 1064-1067. DOI: $10.1111 / \mathrm{jfb} .12041$

Pereira H.H., Neves L.M., da Costa M.R., Araújo F.G. 2015. Fish assemblage structure on sandy beaches with different anthropogenic influences and proximity of spawning grounds. Marine Ecology 36 (1): 16-27. DOI: $10.1111 /$ maec. 12113

Sánchez-Ramárez M., Flores-Coto C. 1998. Growth and mortality of larval Atlantic bumper Chloroscombrus chrysurus (Pisces: Carangidae) in the southern Gulf of Mexico. Bulletin of Marine Science 63 (2): 295-303.

Sossoukpe E., Aissan N.A., Adite A., Fiogbe E.D. 2017. Diagnosis, growth and exploitation rate of the sapater (Chloroscombrus chrysurus, Linnaeus 1766) fishing by purse seine in the nearshore waters of Benin. International Journal of Advanced Fisheries and Aquatic Science 3 (1): 73-89. DOI: 10.23953/cloud. ijafas. 259

Sousa M.F., Fabré N.N., Batista V.S. 2015. Seasonal growth of Mugil liza Valenciennes, 1836 in a tropical estuarine system. Journal of Applied Ichthyology 31 (5): 627-632. DOI: 10.1111/jai.12704

Stebbing A.R.D., Turk S.M.T., Wheeler A., Clarke K.R. 2002. Immigration of southern fish species to south-west England linked to warming of the North Atlantic (1960-2001). Journal of the Marine Biological Association of the United Kingdom 82 (2): 177-180. DOI: $10.1017 / \mathrm{S} 0025315402005325$

Stevens J.D., Hausfeld H.F. 1982. Age determination and mortality estimates on an unexploited population of Jack mackerel Trachurus declivis (Jenyns, 1841) from south-east Australia. CSIRO Marine Laboratories Report, Cronulla, NSW, Australia.
Tarkan A.S., Vilizzi L. 2015. Patterns, latitudinal clines and countergradient variation in the growth of roach Rutilus rutilus (Cyprinidae) in its Eurasian area of distribution. Reviews in Fish Biology and Fisheries 25 (4): 587-602. DOI: 10.1007/s11160-015-9398-6

Tavera J.J., González-Acosta A.F., de la CruzAgüero J. 2008. First record of Seriola peruana (Actinopterygii: Carangidae) in the Gulf of California. Marine Biodiversity Records 1: e4. DOI: 10.1017/ S175526720500028X

Taylor C.C. 1958. Cod growth and temperature. Journal du Conseil international pour l'Exploration de la Mer 23 (3): 366-370. DOI: 10.1093/icesjms/23.3.366

Vazzoler A.E.A.M. 1996. Biologia da reprodução de peixes teleósteos: teoria e prática. [Reproductive biology of teleosteos fish: Theory and practice.] Editora da Universidade Estadual de Maringá (EDUEM), Maringá, Brazil. [In Portuguese.]

Wiedmann M.A., Primicerio R., Dolgov A., Ottesen C.A.M., Aschan M. 2014. Life history variation in Barents Sea fish: Implications for sensitivity to fishing in a changing environment. Ecology and Evolution 4 (18): 3596-3611. DOI: 10.1002/ece3.1203

Wilson J.A., Vigliola L., Meekan M.G. 2009. The backcalculation of size and growth from otoliths: Validation and comparison of models at an individual level. Journal of Experimental Marine Biology and Ecology 368 (1): 9-21. DOI: 10.1016/j.jembe.2008.09.005

Young K.A. 2005. Life-history variation and allometry for sexual size dimorphism in Pacific salmon and trout. Proceedings of the Royal Society B: Biological Sciences 272 (1559): 167-172. DOI: 10.1098/ rspb.2004.2931

Received: 3 October 2017

Accepted: 27 December 2017 Published electronically: 31 March 2018 